\title{
An efficient semi-distributed hillslope erosion model for the subhumid Ethiopian Highlands
}

\author{
S. A. Tilahun ${ }^{1,2}$, C. D. Guzman ${ }^{1}$, A. D. Zegeye ${ }^{3,4}$, T. A. Engda ${ }^{3}$, A. S. Collick ${ }^{1,2}$, A. Rimmer ${ }^{5}$, and T. S. Steenhuis ${ }^{1,2}$ \\ ${ }^{1}$ Department of Biological and Environmental Engineering, Cornell University, Ithaca, NY, USA \\ ${ }^{2}$ School of Civil and Water Resources Engineering, Bahir Dar University, Bahir Dar, Ethiopia \\ ${ }^{3}$ Integrated Watershed Management and Hydrology Program, Cornell University, Bahir Dar, Ethiopia \\ ${ }^{4}$ Adet Research Center, Amhara Regional Agricultural Research Institute, Bahir Dar, Ethiopia \\ ${ }^{5}$ Israel Oceanographic and Limnological Research, The Yigal Allon Kinneret Limnological Laboratory, Migdal, Israel
}

Correspondence to: T. S. Steenhuis (tss1@ cornell.edu)

Received: 5 February 2012 - Published in Hydrol. Earth Syst. Sci. Discuss.: 20 February 2012

Revised: 20 December 2012 - Accepted: 10 January 2013 - Published: 8 March 2013

\begin{abstract}
Erosion modeling has been generally scaling up from plot scale but not based on landscape topographic position, which is a main variable in saturation excess runoff. In addition, predicting sediment loss in Africa has been hampered by using models developed in western countries and do not perform as well in the monsoon climate prevailing in most of the continent. The objective of this paper is to develop a simple erosion model that can be used in the Ethiopian Highlands in Africa. We base our sediment prediction on a simple distributed saturated excess hydrology model that predicts surface runoff from severely degraded lands and from bottom lands that become saturated during the rainy season and estimates interflow and baseflow from the remaining portions of the landscape. By developing an equation that relates surface runoff to sediment concentration generated from runoff source areas, assuming that baseflow and interflow are sediment-free, we were able to predict daily sediment concentrations from the Anjeni watershed with a Nash-Sutcliffe efficiency ranging from 0.64 to 0.78 using only two calibrated sediment parameters. Anjeni is a 113 ha watershed in the 17.4 million ha Blue Nile Basin in the Ethiopian Highlands. The discharge of the two watersheds was predicted with Nash-Sutcliffe efficiency values ranging from 0.80 to 0.93 . The calibrated values in Anjeni for degraded (14\%) and saturated $(2 \%)$ runoff source area were in agreement with field evidence. The analysis suggests that identifying the runoff source areas and predicting the surface runoff correctly is an important step in predicting the sediment concentration.
\end{abstract}

\section{Introduction}

In the African highlands, erosion has occurred for a long time (Hudson, 1957, 1963; Lal, 1985; Nyssen et al., 2004). In colonial times, the devastating effects of soil loss from newly developed agricultural lands was noted and the need to combat it was expressed (Champion, 1933). However, despite large investments in soil and water conservation practices, sediment yields have been increasing in Africa (Lal, 1985; Fleitmann et al., 2007). The reasons mentioned for increased soil loss were greater population pressure and consequently more intensive cultivation (Fleitmann et al., 2007). Moreover, as reported by Mitiku et al. (2006) $40 \%$ of all erosion in Ethiopia is caused by the wrong installation of soil and water conservation (SWC) practices, clearly indicating that our understanding of erosion processes is far from perfect (Hudson, 1987).

For the Blue Nile Basin, a part of the Ethiopian Highlands, reported soil losses vary from 1 to over $400 \mathrm{tha}^{-1} \mathrm{yr}^{-1}$ (Hurni, 1988; Mitiku et al., 2006; Tebebu et al., 2010) with an average of $7 \mathrm{tha}^{-1} \mathrm{yr}^{-1}$, or equivalent to a depth of $0.5 \mathrm{~mm} \mathrm{yr}^{-1}$ (Garzanti et al., 2006). At the same time several large dams are planned in the Blue Nile Basin; therefore, these future developments urgently need better ways to reduce soil loss in order to sustain the efficient operation of the dams well into the future.

In the coming decades, models will play an important role in predicting sediment concentration and loads for reservoirs in the Blue Nile Basin. The Grand Ethiopian Renaissance 
Dam near the Ethiopian-Sudan border is currently being built and several other dams are being planned. In the past, several models have been used in the (semi) humid Ethiopian Highlands to predict discharge and soil loss. Models that employ the SCS curve number method (infiltration excess runoff) for runoff are the Agricultural Non-Point Source Pollution (AGNPS) model (Haregeweyn and Yohannes, 2003; Mohammed et al., 2004), the Water Erosion Prediction Project (WEPP) model (Zeleke, 2000) and the Soil and Water Assessment Tool (SWAT) (Setegn et al., 2008). These models need detailed soil and land use data that is not available in the Ethiopian Highlands. Moreover, these models do not simulate saturation excess, which is the dominant runoff mechanism in the Ethiopian Highland (Bayabil et al., 2010; Liu et al., 2008). The modified SWAT-WB Water Balance model (Easton et al., 2010; White et al., 2010) includes saturation excess runoff and gives better results than models used previously. However, data requirements are even greater than for the standard SWAT model.

An additional limitation with these models is that they use the standard Universal Soil Loss Equation (USLE) (Wischmeier and Smith, 1978) or related versions (such as the one modified for Ethiopian conditions; Hurni, 1985; Eweg et al., 1998; and Zegeye et al., 2010) where the parameters values are based on small plot measurements. Despite using rigorous, theoretically justified erosion prediction routines in WEPP, it did not perform well because runoff predictions were based on the infiltration excess (Zeleke, 2000).

Thus, scaling up USLE (i.e., plot scale) estimates to watershed- or basin-scale invariably leads to overestimation or underestimation of soil loss at the outlet (Vanmaercke et al., 2011). Discussions of scaling up are not only limited to erosion. For example, for discharge predictions Savenije (2010) writes, "physically based small scale basic principles (such as the Darcy, Richards, and Navier-Stokes equations) with detailed distributed modeling, leads to equifinality and high predictive uncertainty, mostly because these methods ill account for heterogeneity, preferential pathways and structural patterns on and under the surface". Other researchers argue that Darcy's and Richards' law apply and can predict with a reasonable degree of accuracy the moisture contents and leaching patterns after some calibration of the parameters (Kung et al., 2000; Kim et al., 2005; Zehe et al., 2010; Klaus and Zehe, 2011). Although, due to the lack of fine and detailed information, the best way of finding the regularity in the "calibration" parameters is being intensively researched, there is agreement that there exists some measure of organized complexity in naturally formed catchments at intermediate and larger scales (Dooge, 1986, 2005; Savenije, 2010; He et al., 2011). Field research such as in the semihumid Ethiopian Highlands (Bayabil et al., 2010); Catskill Mountains (in New York State, Lyon et al., 2006; de Alwis et al., 2007; Harpold et al., 2010; Dahlke et al., 2012) and Australia (Western et al., 2002) confirms that these emerging patterns of self-organization in watersheds exist because of the similarity in moisture contents from year to year.

Many different approaches are being developed to incorporate this organized complexity into discharge predictions (Borga et al., 2011; Rimmer and Hartmann, 2012; and Sivapalan et al., 2011). These models are often much simpler when compared with models that use Darcy's law and conservation of mass (Dooge, 1986, 2005; and Savenije, 2010). Our nine-parameter hydrology model, using just three fractional areas that produce either overland flow or subsurface flow, developed for the Ethiopian Highlands (Steenhuis et al., 2009; and Tesemma et al., 2010), is an example of such a model.

The objective of this study is therefore to develop an erosion model that goes beyond scaling up plot erosion estimates, to improve sediment concentration prediction for a monsoon climate prevailing in the Ethiopian Highlands at several scales. Our erosion model will use the patterns of self-organization introduced by Savenije (2010) to model the discharge and the sediment concentration of two watersheds in the Ethiopian Highlands varying greatly in size. To the best of our knowledge, this is the first attempt to include organized complexity in sediment concentrations predictions at the watershed scale.

In this new approach, we combine the hydrology model of Steenhuis et al. (2009) and Tesemma et al. (2010) with an erosion model. The hydrology model employs organized complexity to define the areas that recharge the subsurface storages and generate surface runoff. Magnitude of the fluxes is calculated with a water balance type approach. The erosion model assumes a linear relationship between sediment concentration and velocity from runoff-producing areas. It also assumes dilution with interflow similar to the sediment concentration prediction approach in Steenhuis et al. (2009). The physical justification for our semi-distributed sediment model closely follows Hairsine and Rose (1992a, b), as implemented by Rose (1993), and the models of Ciesiolka et al. (1995) and Yu et al. (1997). The Hairsine and Rose model predicted sediment concentrations successfully in the monsoon climate of the Philippines, Thailand and Malaysia using observed stream flows (Rose, 2001). In the foothills of Nepal, soil erosion from USLE-type plots was predicted most accurately by WEPP, followed by the Griffith University Erosion System Template (GUEST) Technology (based on Hairsine and Rose Model), and European Soil Erosion Model (EUROSEM) (Kandel et al., 2001). In this manuscript, we introduce the model development and illustrate its capacity to simulate Ethiopian Highland hydrology and erosion. 


\section{Material and methods}

\subsection{Description of Anjeni watershed and Blue Nile Basin}

Sediment concentration data are available for a few watersheds in Ethiopia. These watersheds were established by the Soil Conservation Research Program (SCRP) as a collaborative project of the University of Bern, Switzerland, and the Ministry of Agriculture, Ethiopia. This watershed is in the Ethiopian Highlands and drains into the Blue Nile Basin initiated in 1981 in order to support and monitor SWC efforts in the highlands of Ethiopia. In this paper, we use the data of one of these experimental watersheds located in the Ethiopian Highlands, Anjeni, and the Ethiopian Blue Nile Basin at the Ethiopian-Sudan border.

The Anjeni watershed (Fig. 1 and Table 1) covers an area of 113.4 ha, with elevations ranging between 2405 and $2507 \mathrm{~m}$. It is located approximately at the center of the Blue Nile Basin that covers 17400000 ha. Anjeni is subhumid in climate, while the Blue Nile flows from humid to semiarid climates on the way to the Ethiopian-Sudan border. The annual rainfall of the basin ranges from approximately $2000 \mathrm{~mm}$ in the southeast to nearly $1000 \mathrm{~mm}$ in the northeast and $1690 \mathrm{~mm}$ at Anjeni. The rainfall at Anjeni is unimodal, which lasts from the middle of May to the middle of October. Mean daily temperature ranges from approximately $6^{\circ} \mathrm{C}$ to $25^{\circ} \mathrm{C}$ in the basin as well as in the Anjeni watershed.

The basin has a rugged topography and considerable variation in altitude, ranging from $480 \mathrm{~m}$ to $4260 \mathrm{~m}$ and highly incised by Blue Nile River and its tributaries in the northwest direction. The highlands of the basin are mainly basaltic rock and the lower part is predominantly basement complex rocks. The Anjeni watershed at the highland of the basin is oriented north-south and flanked on three sides by plateau ridges. Most of the watershed is on slopes ranging from 8 to $30 \%$. The geological formation of this watershed area belongs to the basaltic Trap series of the Tertiary volcanic eruptions, and the topography of the area is deeply incised by streams (Zeleke, 2000). There is high gully formation at the upper part of the watershed, where a perennial spring is located at the head of the gully and becomes a source for a river called Minchet.

Alisols and Leptosols (21\%), Nitosols (16\%) and Vertisols $(15 \%)$ are the dominant soil types in the basin with shallow and permeable soil underlain by bedrock on the highlands and deeper soil at the lower reaches of the basin and its tributaries (Betrie et al., 2011). The soils of Anjeni have developed on the basalt and volcanic ash of the plateau. The southern part of the watershed with valley floors at the outlet of the watershed and the depressions of the foothills consist of deep and highly conductive Humic Alisols and Haplic Nitosols, while moderately deep Cambisols cover the middle area, and the shallow Haplic Alisols and Humic Nitosols cover the hillsides, indicating land degradation processes

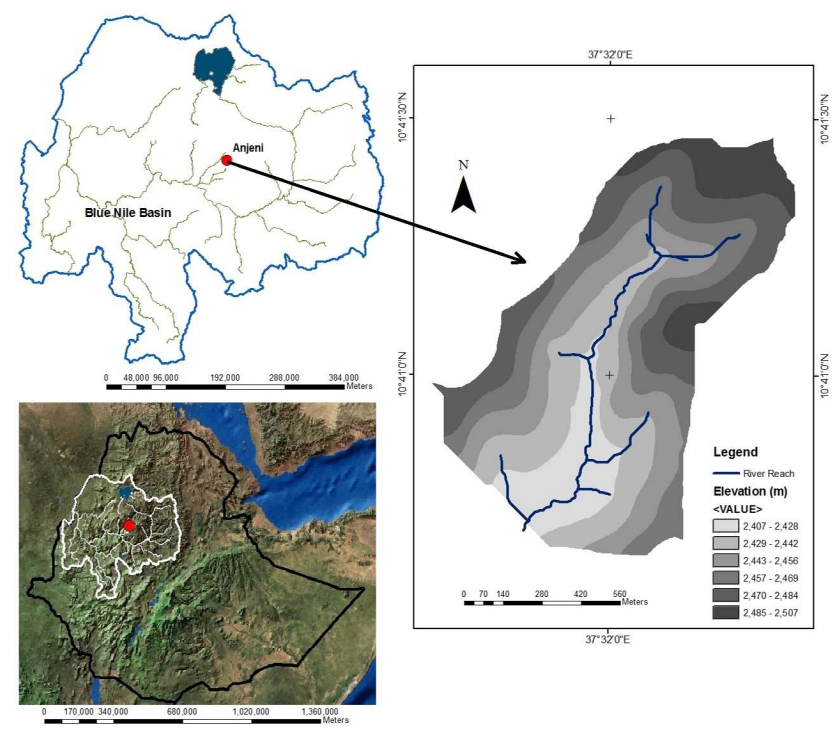

Fig. 1. Watershed boundary and drainage map of Anjeni (a) with its location in the Blue Nile Basin (b) and in the map of Ethiopia (c).

(Zeleke, 2000). The very shallow Regosols and Leptosols soils cover $12 \%$ of the hillsides (Leggesse, 2009).

Before 1986, no management activities existed in the Anjeni watershed and the hydrology events were monitored without any SWC (SCRP, 2000). Fanya juu (SWC structure comprised of a bund above and a drainage ditch below the bund; Thomas and Biamah, 1991) were then constructed in early 1986 throughout the watershed and by 1992 had generally developed into terraces (Fig. 4, Hanggi, 1997).

Baseflow and interflow significantly affect daily sediment concentration calculations. To demonstrate this, two storms are depicted: one in the beginning of the rainy season (24 April 1992, Fig. 2a), and one later in the main rainy season (19 July 1992, Fig. 2b). The surface runoff for both events is similar, with peak runoff at $400-500 \mathrm{~L} \mathrm{~s}^{-1}$ above the flow recorded prior to the beginning of the storm, with peak sediment concentrations around $30-35 \mathrm{gL}^{-1}$. Despite the similar surface runoff characteristics, the April discharge was $2.4 \times 10^{3} \mathrm{~m}^{3} \mathrm{day}^{-1}$, and for July it was $6.5 \times 10^{3} \mathrm{~m}^{3} \mathrm{day}^{-1}$. The difference in magnitude is because of baseflow discharge increases during the rainy phase of the monsoon $\left(10 \mathrm{~L} \mathrm{~s}^{-1}\right.$ in April and $50 \mathrm{~L} \mathrm{~s}^{-1}$ in July). The average daily sediment concentration is obtained by dividing the total sediment load by the total flow resulting in concentrations of $11 \mathrm{~g} \mathrm{~L}^{-1}$ for the April storm and $4.4 \mathrm{~g} \mathrm{~L}^{-1}$ for the July storm. In essence, the baseflow dilutes the peak storm concentration when simulated on a daily basis later in the rainy season. It is, therefore, important to incorporate the contribution of baseflow in the prediction of sediment concentration. 
Table 1. Location, description, and data used in the model for the Anjeni sites (SCRP, 2000).

\begin{tabular}{|c|c|}
\hline \multicolumn{2}{|l|}{ Area Description } \\
\hline Size of the area (ha) & 113.4 \\
\hline Location & $37^{\circ} 31^{\prime} \mathrm{E}$ and $10^{\circ} 40^{\prime} \mathrm{N}$ \\
\hline Elevation (m a.s.l) & $2405-2507$ \\
\hline Mean Annual Rainfall (mm) & 1690 \\
\hline \multicolumn{2}{|l|}{ Length of Data } \\
\hline Precipitation $\left(\mathrm{mm} \mathrm{day}^{-1}\right)$ & $1988-1997$ \\
\hline Potential evaporation $\left(\mathrm{mm}_{\mathrm{day}}{ }^{-1}\right)$ & $\begin{array}{l}\text { 1988-1997 (1995-1996 } \\
\text { incomplete) }\end{array}$ \\
\hline Stream flow $\left(\mathrm{mm} \mathrm{day}^{-1}\right)$ & $1988-1997$ \\
\hline Sediment concentration $\left(\mathrm{g} \mathrm{L}^{-1}\right)$ & $\begin{array}{l}1988-1997 \text { (1988, } 1994 \text { and } \\
1997 \text { incomplete) }\end{array}$ \\
\hline \multicolumn{2}{|l|}{ Periods regarding conservation practices } \\
\hline No conservation & 1984-1985 \\
\hline Fanya Juu conservation implementation & 1986 \\
\hline Full terraces developed & 1992 \\
\hline
\end{tabular}

\section{Model development}

The model described below predicts daily sediment concentrations by assuming that all erosion is produced in areas contributing surface runoff. These areas consist of degraded hillsides with shallow soils and saturated areas formed during the rainy phase. Erosion rates are greater from the more heavily degraded areas without plant cover than from the saturated source areas with natural vegetation. Erosion is negligible from the non-degraded hillsides because almost all water infiltrates (Bayabil et al., 2010; Engda et al., 2011).

\subsection{Hydrology model}

The watershed is divided into three regions (Fig. 3). The first two surface runoff source areas consist of areas near the river that become saturated during the wet monsoon period, and the degraded hillsides with little or no soil cover. The remaining hillsides are the third zone, where rainwater on the hillside infiltrates and becomes either interflow or baseflow, depending on its path to the stream. A daily water balance is kept for each of the regions using the Thornthwaite-Mather procedure (Thornthwaite and Mather, 1955; Steenhuis and van der Molen, 1986) for calculating the actual evaporation. Overland flow is simulated when the soil is at saturation for the potentially saturated areas and the degraded hillsides (Fig. 3). Since the soil in the degraded areas is shallow, only minor amounts of rainfall are required before the soil saturates and runoff is produced. When the soil on the hillsides reaches field capacity, additional rainfall is released to two types of subsurface flow: the first order baseflow reservoir and a zero order interflow reservoir (Fig. 3). The first order (baseflow) is characterized by an exponentially decreasing flow in time, with a watershed specific half-life. The zero order (interflow) is relatively fast and characterized by a flow decrease as a linear function of time, and lasts for a
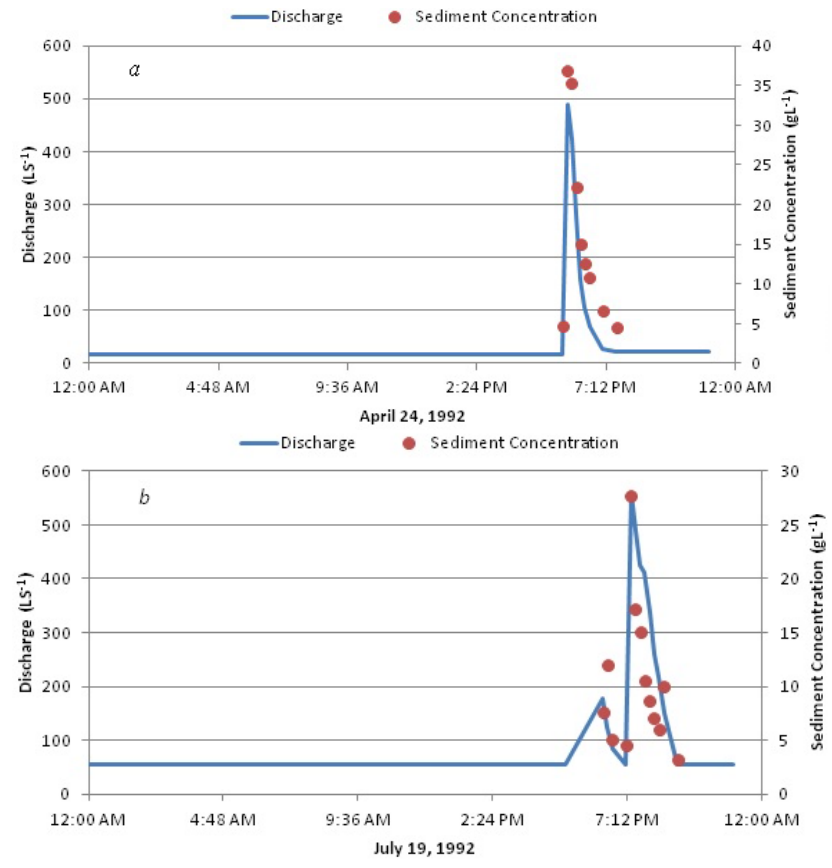

Fig. 2. Measured discharge $\left(\mathrm{Ls}^{-1}\right)$ and sediment concentration $\left(\mathrm{g} \mathrm{L}^{-1}\right)$ during (a) 24 April 1992 and (b) 19 July 1992 for Anjeni watershed.

fixed time $\left(t^{*}\right)$ after a rainstorm. The time $t^{*}$ is landscapedependent but invariant of storm size. In order to separate interflow from baseflow, we assume that the first order baseflow reservoir fills up first and then the remaining recharge is contributed to the zero order interflow reservoir through percolation (Fig. 3). More details on the daily water balance and subsurface flow equations are given in Steenhuis et al. (2009) and Tesemma et al. (2010) where the model was applied to the whole Blue Nile Basin using a Microsoft Excel spreadsheet.

Inputs to the model are daily rainfall and potential evaporation. Input parameters of the model are the extent of the three areas in the watershed, the amount of storage in the soil between wilting point and saturation for the runoffproducing areas, and wilting point and field capacity for the hillside. In addition, there are three more subsurface parameters: a maximum storage and half-life for the first order groundwater reservoir, and the time it takes for a hill slope to drain after a rain storm for the linear interflow reservoir.

\subsection{Sediment model}

In the sediment model, we assume for simplicity that the erosion process is a unique function of the velocity $v$. Then, as shown in the Supplement for the two source areas, the concentration $C\left(\mathrm{~kg} \mathrm{~m}^{-3}\right)$ is a function of flow rate and a coefficient (for each source area) dependent on landscape and sediment characteristics (Hairsine and Rose, 1992a, b; Rose 


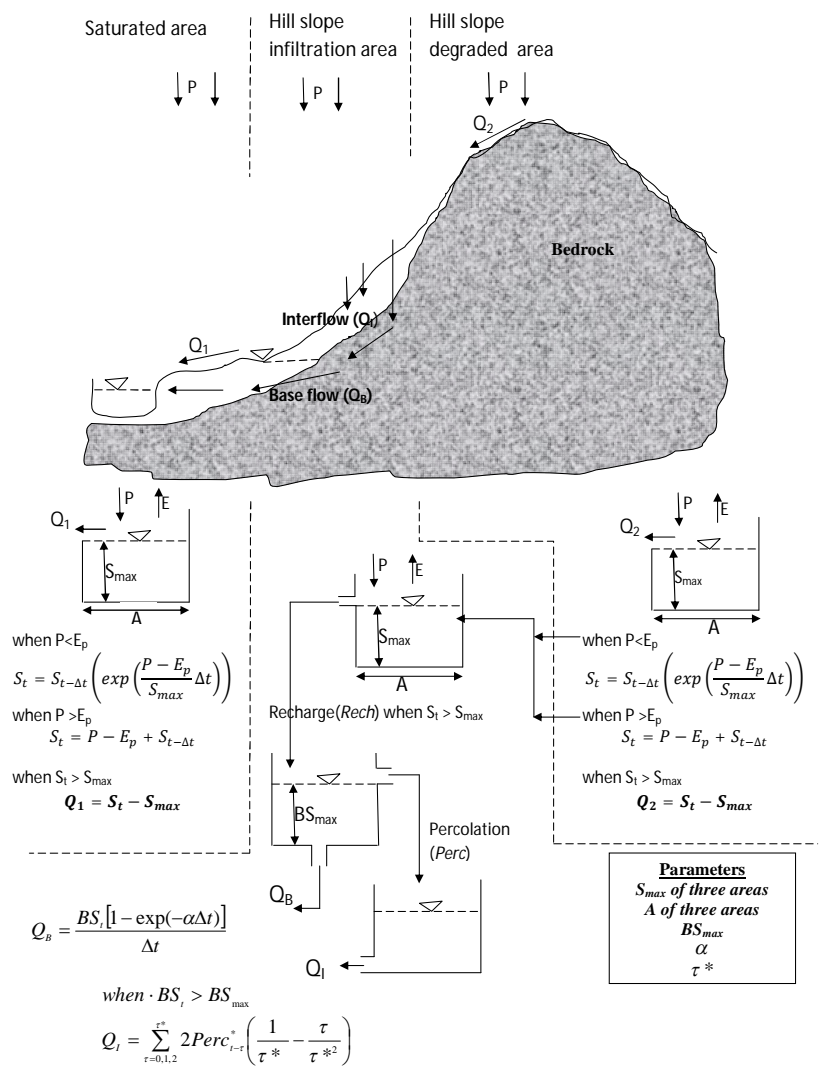

Fig. 3. Schematic of the hydrology model where $P$ is precipitation; $E_{\mathrm{p}}$ is potential evaporation; $A$ is area fraction for components of 1-saturated area, 2-degraded area and 3-infiltration areas; $S_{\max }$ is maximum water storage capacity of the three areas; $\mathrm{BS}_{\max }$ is maximum baseflow storage of linear reservoir; $t_{1 / 2}(=0.69 / \alpha)$ is the time it takes in days to reduce the volume of the baseflow reservoir by a factor of two under no recharge condition; and $\tau^{*}$ is the duration of the period after a single rainstorm (until interflow ceases).

et al., 1993; Siepel et al., 2002; Ciesiolka et al., 1995 and Yu et al., 1997).

$C=a Q^{n}$,

where $Q$ is the runoff rate per unit area from each source area $\left(\mathrm{m} \mathrm{day}^{-1}\right)$, and $a$ is a constant which is a function of the slope, Manning's roughness coefficient, slope length, the effective deposition and vegetation cover (Yu et al., 1997). The exponent $n$ is 0.4 when the width of flow is much larger than the water depth on the runoff-producing areas (Ciesiolka et al., 1995 and Yu et al., 1997). As water depth increases, $a$ essentially becomes independent of the runoff rate and can be taken as a constant such as in this application where we are interested in sediment concentration at the outlet of watersheds of over 100 ha (Lisle et al., 1996).

Sediment yield, $\left(\mathrm{tday}^{-1} \mathrm{ha}^{-1}\right) Y_{i}$, for each of the two runoff source areas, $i$, then becomes

$Y_{i}=a Q_{i} Q_{i}^{0.4}$.
To calculate the suspended sediment concentration at the watershed outlet, we note that the total discharge $Q$ from the three areas at time $t$ can be written in terms of the contributions of the three areas delineated in the watershed:

$Q=A_{1} Q_{1}+A_{2} Q_{2}+A_{3}\left(Q_{\mathrm{B}}+Q_{\mathrm{I}}\right)$,

where $Q_{1}$ and $Q_{2}$ are the runoff rates expressed in depth units for contributing area; $A_{1}$ is the fractional saturated area; and $A_{2}$ is the fractional degraded area. $A_{3}$ is the fractional contributing area for baseflow, $Q_{\mathrm{B}}$ and interflow, $Q_{\mathrm{I}}$.

Sediment yield in the stream depends on the amount of suspended sediment delivered by each component of the stream flow. The daily sediment yield equation in its most general form is

$Y=A_{1} Q_{1} C_{1}+A_{2} Q_{2} C_{2}+A_{3}\left(Q_{\mathrm{B}} C_{\mathrm{B}}+Q_{\mathrm{I}} C_{\mathrm{I}}\right)$,

where $C_{1}$ and $C_{2}$ are the sediment concentration in runoff from the saturated area, and degraded area, respectively; $C_{\mathrm{B}}$ is the sediment concentration in the baseflow and $C_{\mathrm{I}}$ the concentration in interflow. Recalling that sediment concentration, $C$, is related to the discharge as shown in Eq. (1), Eq. (4) can be rewritten as

$Y=a_{1} A_{1} Q_{1}^{n+1}+a_{2} A_{2} Q_{2}^{n+1}+A_{3}\left(a_{\mathrm{B}} Q_{\mathrm{B}}^{n+1}+a_{\mathrm{I}} Q_{\mathrm{I}}^{n+1}\right)$,

which simplifies to a relationship between sediment yield and discharge for $n=0.4$

$Y=a_{1} A_{1} Q_{1}^{1.4}+a_{2} A_{2} Q_{2}^{1.4}+A_{3}\left(a_{\mathrm{B}} Q_{\mathrm{B}}^{1.4}+a_{\mathrm{I}} Q_{\mathrm{I}}^{1.4}\right)$.

The superscript of $Q$ in Eq. (6) is within the range from 0.5 to 2 in the most common sediment transport capacity models (Prosser and Rustomji, 2000). By dividing Eq. (6) by the total discharge (Eq. 3) and taking the sediment concentration in the base and interflow as zero (i.e., $a_{\mathrm{B}}=0$ and $a_{\mathrm{I}}=0$ ), the sediment concentration can be found as

$C=\frac{a_{1} A_{1} Q_{1}^{1.4}+a_{2} A_{2} Q_{2}^{1.4}}{A_{1} Q_{1}+A_{2} Q_{2}+A_{3}\left(Q_{\mathrm{B}}+Q_{\mathrm{I}}\right)}$.

All parameters in Eq. (7) can be obtained from the hydrologic simulation, with the exception of $a_{1}$ and $a_{2}$, which need to be calibrated with existing field data.

\subsection{Input data}

Since the 1984 establishment of the Anjeni micro-watersheds by the Soil Conservation Research Project (SCRP), fineresolution data on climate, hydrology, and suspended sediment from both river and test plots have been collected. In addition, an expansive database has been established that serves as a data source to carry out hydrological, soil erosion, and conservation research activities at regional, national, and international levels. This watershed provided the most comprehensive data of daily rainfall, potential evaporation, stream flow, and sediment concentrations (Mitiku et al., 2006). 
Table 2. Calibrated parameters for daily and 10-day stream flows and sediment concentration modeling in the Anjeni watershed and Blue Nile Basin, respectively.

\begin{tabular}{|c|c|c|c|c|c|}
\hline \multirow[b]{2}{*}{ Components } & \multirow[b]{2}{*}{ Description } & \multirow[b]{2}{*}{ Parameters } & \multirow[b]{2}{*}{ Unit } & \multicolumn{2}{|c|}{ Calibrated values } \\
\hline & & & & Anjeni & $\begin{array}{l}\text { Blue } \\
\text { Nile }\end{array}$ \\
\hline \multirow[t]{9}{*}{ Hydrology } & \multirow[t]{2}{*}{ Saturated area } & Area $A_{1}$ & $\%$ & 2 & 20 \\
\hline & & $S_{\max }$ in $A_{1}$ & $\mathrm{~mm}$ & 200 & 200 \\
\hline & \multirow[t]{2}{*}{ Degraded area } & Area $A_{2}$ & $\%$ & 14 & 20 \\
\hline & & $S_{\max }$ in $A_{2}$ & $\mathrm{~mm}$ & 10 & 10 \\
\hline & \multirow[t]{2}{*}{ Hill side } & Area $A_{3}$ & $\%$ & 50 & 60 \\
\hline & & $S_{\max }$ in $A_{3}$ & $\mathrm{~mm}$ & 100 & 300 \\
\hline & \multirow[t]{3}{*}{ Subsurface flow parameters } & $\mathrm{BS}_{\max }$ & $\mathrm{mm}$ & 100 & 20 \\
\hline & & $t_{1 / 2}$ & days & 70 & 35 \\
\hline & & $\tau^{*}$ & days & 10 & 140 \\
\hline \multirow[t]{4}{*}{ Sediment } & \multirow[t]{2}{*}{ Subsurface flow } & $a_{\mathrm{B}}$ & $\left(\mathrm{g} \mathrm{L}^{-1}\right)\left(\mathrm{mm} \mathrm{day}^{-1}\right)^{-0.4}$ & 0 & 0 \\
\hline & & $a_{\mathrm{I}}$ & $\left(\mathrm{g} \mathrm{L}^{-1}\right)\left(\mathrm{mm} \mathrm{day}^{-1}\right)^{-0.4}$ & 0 & 0 \\
\hline & Saturated area & $a_{1}$ & $\left(\mathrm{~g} \mathrm{~L}^{-1}\right)\left(\mathrm{mm} \mathrm{day}^{-1}\right)^{-0.4}$ & 0.2 & 0.2 \\
\hline & Degraded area & $a_{2}$ & $\left(\mathrm{~g} \mathrm{~L}^{-1}\right)\left(\mathrm{mm} \mathrm{day}^{-1}\right)^{-0.4}$ & 3.40 & 1.2 \\
\hline
\end{tabular}

Stream flow and sediment concentration were measured at a station located at the outlet of the Anjeni watershed by SCRP. The depth of water was taken with float-actuated recorders. The water level in the stream was measured at 08:00 a.m. LT daily. In case of peak stream flow events, water level measurements and sediment samples were recorded at ten-minute intervals during the event and every $30 \mathrm{~min}$ when water level decreased. Discharge was evaluated using the relation between water level and stream discharge (Bossahart, 1997). The river stage-discharge relationship was determined using salt dilution and current meter methods.

To determine sediment concentration during the storm, one-liter samples were taken from the river at the gauging station. Sampling started once the water at the gauging station looked turbid (brown), and the sampling continued at 10 min intervals. When runoff became clearer, the sampling interval was extended to thirty minutes, and sampling continued until the runoff was visibly sediment-free. The collected water samples were filtered using filter paper, sundried, and oven dried, and finally weighed to calculate the net dry soil loss of the sample. Event-based sediment yields were summed over a daily period to determine daily sediment load. Daily sediment concentration was determined by dividing the daily sediment load by the total discharge during that day. These were then compared to the daily predicted sediment concentrations.

\subsection{Model calibration and validation}

\subsubsection{Data}

We first calibrate daily discharge values with the water balance model and subsequently the sediment concentration values with the sediment model of Eq. (7). The data used in the model is summarized in Table 1. In Anjeni, the period from 1988 to 1997 was used as data source for daily rainfall, potential evaporation and stream flow in this study. The data from 1988 and 1990 were used for calibration of the water balance model (Table 2) and from 1989, 1991-1994 and 1997 for validation. The climate data for the years 1995 and 1996 were incomplete and excluded from the model development processes.

For the sediment modeling, the year 1990 was used for calibration and the period 1991-1993 was used for validation. The sediment concentration data of 1989 was excluded because of very low sediment concentration measurements. The low concentrations might have been caused by soil bunds (Fanya juu) installed in the watershed in 1986 that captured all sediment effectively. Equilibrium was likely established in 1990, when the terraces were formed behind the bunds in the runoff source area (Hanggi, 1997).

Available sediment concentration data for the Blue Nile at the Sudan border was limited to three years: 1993, 2003 and 2004. The period of 1993 was used to calibrate both hydrology and sediment models in the Blue Nile Basin while the other two years - 2003 and 2004 - were used for validation. 


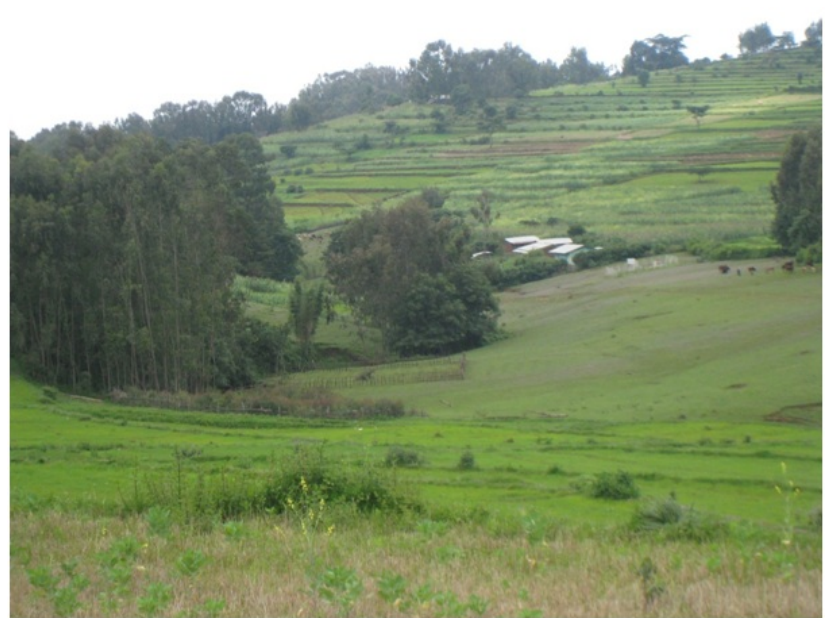

Fig. 4. Flank portion of the Anjeni watershed at the background, which was developed to full terraces from Fanya juu conservation practices and the deep soil with saturated area at the forefront.

\subsubsection{Methods of calibration and validation}

All nine parameters were calibrated for the hydrology model (Table 2). Initial values for calibrating parameters were based on Steenhuis et al. (2009) and Collick et al. (2009). These initial values were changed manually through randomly varying calibrated parameters in order that the best "closeness" or "goodness-of-fit" was achieved between simulated and observed subsurface and overland flow in the watershed. The goodness-of-fit and the model performance were measured and evaluated using the Nash-Sutcliffe Efficiency (NSE) coefficient, coefficient of determination $\left(R^{2}\right)$ and the Root Mean Squared Error (RMSE).

For partitioning rainfall into surface runoff, size $(A)$ and maximum storage capacity $\left(S_{\max }\right)$ are the important parameters considered in the three areas. For the subsurface reservoirs, the parameters considered were half-life $\left(t_{1 / 2}\right)$ and maximum storage capacity $\left(\mathrm{BS}_{\max }\right)$ of a linear aquifer and the drainage time of the zero order reservoir $\left(\tau^{*}\right)$.

In the sediment model, daily sediment concentration was computed first by calculating daily sediment load then dividing the daily load by the total daily stream flow using Eq. (7). In the equation, there are two calibration parameters consisting of the constants for each of the two runoff source areas $a_{1}$ and $a_{2}$. These constants are changed manually in order to get a best fit between measured and simulated daily sediment concentration.

\section{Results and discussion}

The calibrated parameters are shown in Table 2 and the goodness of fit as determined by the Nash-Sutcliffe Efficiency (NSE), coefficient of determination $R^{2}$ and root mean squared error (RMSE) for the hydrology and sediment model

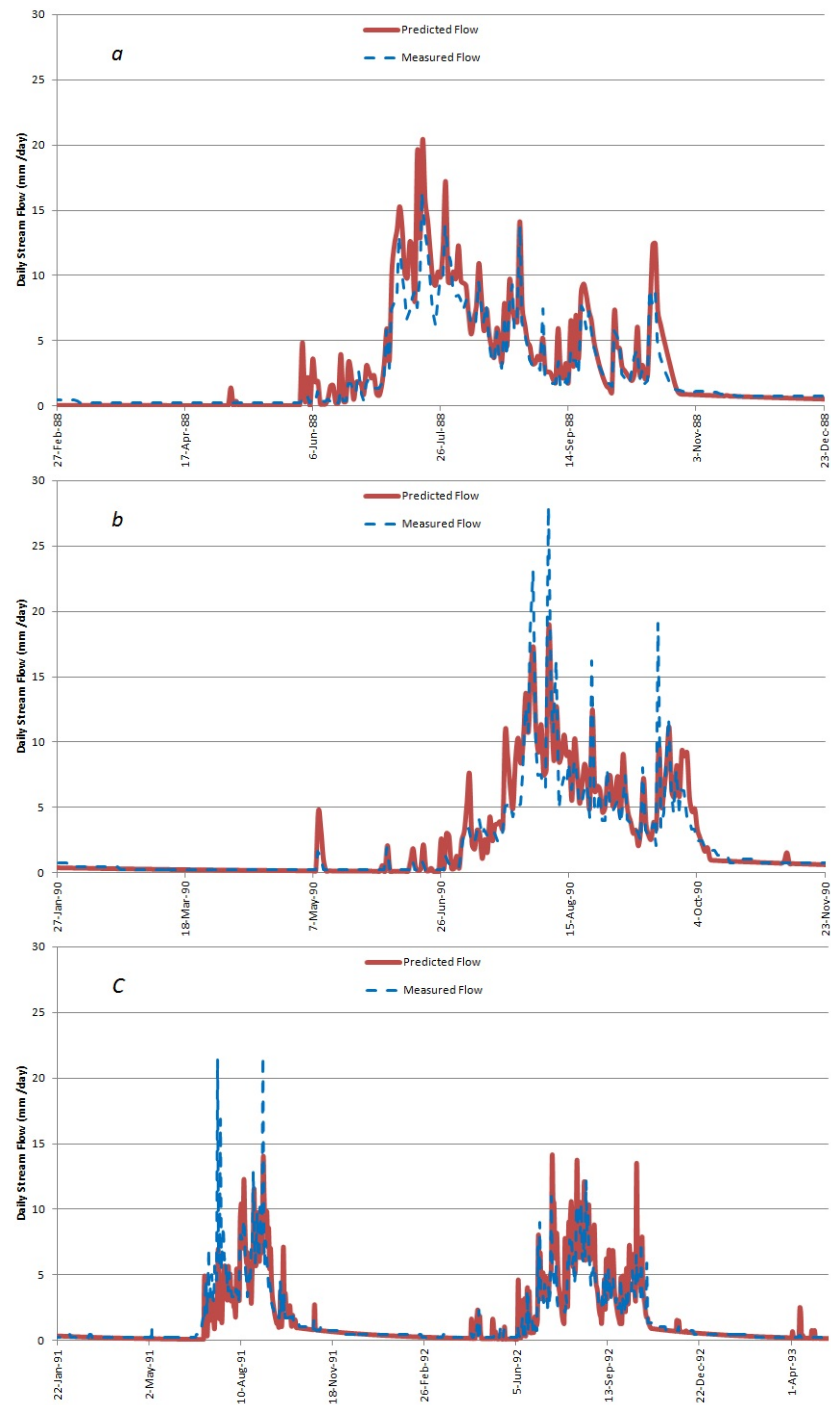

Fig. 5. (a) Predicted and observed daily stream flow for Anjeni watershed; (b) calibrated discharge using 1988 and 1990 daily data; and (c) validated discharge (shown only for 1991 and 1992).

are presented in Table 3. A comparison of predicted and observed daily stream flow for the Anjeni watershed is shown in Fig. 5 and in the Supplement Fig. S1 and predicted and measured sediment concentration in Fig. 6 and Fig. S2 in the Supplement. For the Blue Nile Basin, Fig. 7 shows both predicted and observed 10-day stream flow, and 10-day average sediment concentration was shown in Fig. 8.

\subsection{Hydrology model}

The hydrology model performed quite well (Table 3) for both the Anjeni watershed (Fig. 5) and the Blue Nile Basin (Fig. 7). The model calibration suggests (Table 2) that $14 \%$ of the Anjeni watershed and $20 \%$ of the Blue Nile Basin consist of degraded area with shallow soil or exposed hardpan, which requires only a little rain to generate direct runoff (i.e., 
Table 3. Runoff $(Q)$ and sediment concentration $(C)$ simulation efficiency as evaluated by statistical measures for daily time step in Anjeni watershed and Blue Nile Basin.

\begin{tabular}{|c|c|c|c|c|c|c|}
\hline \multirow[b]{3}{*}{ Site } & & & \multicolumn{2}{|c|}{ Stream flow (mm) } & \multicolumn{2}{|c|}{ Sediment Concentration $\left(\mathrm{g} \mathrm{L}^{-1}\right)$} \\
\hline & & & Calibration & Validation & Calibration & Validation \\
\hline & \multicolumn{2}{|c|}{ Year } & $1988 \& 1990$ & $1989 \& 1991-1997$ & 1990 & $1991-1993$ \\
\hline \multirow[t]{7}{*}{ Anjeni } & Mean & Observed & 2.1 & 1.9 & 0.72 & 0.67 \\
\hline & & Predicted & 2.3 & 1.9 & 0.65 & 0.65 \\
\hline & Standard & Observed & 3.2 & 2.7 & 2.24 & 2.19 \\
\hline & Deviation & Predicted & 3.6 & 2.8 & 1.94 & 1.78 \\
\hline & Statistical & NSE & 0.86 & 0.80 & 0.78 & 0.64 \\
\hline & Parameters & $R^{2}$ & 0.88 & 0.82 & 0.80 & 0.67 \\
\hline & & RMSE & 1.6 & 1.5 & 1.66 & 1.32 \\
\hline \multirow[t]{8}{*}{ Blue Nile Basin } & \multicolumn{2}{|c|}{ Year } & 1993 & 2003-2004 & 1993 & 2003-2004 \\
\hline & \multirow{2}{*}{ Mean } & Observed & 9.7 & 9.4 & 0.85 & 1.28 \\
\hline & & Predicted & 9.5 & 9.2 & 1.26 & 0.92 \\
\hline & \multirow{2}{*}{$\begin{array}{l}\text { Standard } \\
\text { Deviation }\end{array}$} & Observed & 9.9 & 9.9 & 1.51 & 2.32 \\
\hline & & Predicted & 11.8 & 9.2 & 1.98 & 1.87 \\
\hline & \multirow{3}{*}{$\begin{array}{l}\text { Statistical } \\
\text { Parameters }\end{array}$} & NSE & 0.93 & 0.92 & 0.76 & 0.76 \\
\hline & & $R^{2}$ & 0.97 & 0.93 & 0.88 & 0.80 \\
\hline & & RMSE & 2.6 & 2.7 & 0.73 & 1.89 \\
\hline
\end{tabular}

$S_{\max }=10 \mathrm{~mm}$ ) and approximately $2 \%$ of Anjeni and $20 \%$ of Blue Nile Basin are saturated bottom lands that needed $200 \mathrm{~mm}$ of effective precipitation to generate runoff (i.e., $S_{\max }=200 \mathrm{~mm}$ ). The hillside, or the infiltration (recharge) areas, in Anjeni and Blue Nile Basin represent $50 \%$ and $60 \%$, respectively, of the total area and require $100 \mathrm{~mm}$ and $300 \mathrm{~mm}$ of effective precipitation to reach field capacity. Thirty-four percent of the discharge in the Anjeni watershed is not accounted for and leaves the watershed as deep regional flow through the deep soil profile at the outlet of the watershed, while this cannot be (and is not) the case for the Blue Nile Basin.

In the Anjeni watershed, the small proportion of saturated area is consistent with the piezometer readings of Leggesse (2009) that showed a deep water table throughout the uniformly steep watershed except in very close proximity to the stream (Fig. 4). This is unlike the Maybar (Bayabil et al., 2010) and Andit Tid (Engda et al., 2011) watersheds, where large flat areas near the river usually saturate during the rainy season with annual precipitation over $500 \mathrm{~mm}$ (Liu et al., 2008). In the Anjeni watershed, where the soils are deep at the middle and lower part and there are no flat areas, all the water that otherwise would have saturated the soil, drains directly into the stream. The $14 \%$ degraded area is slightly overpredicting the shallow soil, covering $12 \%$ the watershed (Zeleke, 2000; Leggesse, 2009). This is consistent with sensitivity results on the validation years, indicating a smaller degraded area than indicated by the calibration would fit better. The maximum baseflow storage $\left(\mathrm{BS}_{\max }\right)$ was calibrated to $100 \mathrm{~mm}$ and $\tau^{*}$ was 10 days for the watershed. The half-life of baseflow storage was set to be 70 days. In the Blue Nile, $\tau^{*}$ was 140 days, much greater than in Anjeni, since the larger basin receives more deep flows than are intercepted by the Blue Nile River. However, the half-life of the Blue Nile Basin was 35 days, two times less than the value for the Anjeni watershed. The slower response for Anjeni was expected because the rainfall that does not flow through its outlet takes a longer path to reach the river system.

The good fit in Figs. 5 and 7 and Figs. S1 and S2 in the Supplement was confirmed by the performance statistics. The $R^{2}$, NSE and RMSE values for Anjeni (Table 3) were $0.88,0.86$ and $1.6 \mathrm{~mm}$, for calibration and $0.82,0.80$ and $1.5 \mathrm{~mm}$ for validation, indicating that the model has reasonably captured the watershed response to rainfall. For the case of the Blue Nile, the $R^{2}$, NSE and RMSE values were 0.97 , 0.93 and $2.6 \mathrm{~mm}$ for calibration and $0.93,0.92$ and $2.7 \mathrm{~mm}$ for validation.

Despite the good statistics, the model overpredicted low flows and underpredicted flows of greater than $20 \mathrm{~mm} \mathrm{day}^{-1}$ during the calibration period for Anjeni (Figs. 5a, b and 7a). The same is true for the Blue Nile Basin, where the peak flows during August were underestimated during the calibration period, 1993 (Fig. 7a). During validation (Figs. 5c and $7 \mathrm{~b}$ ), there is a reasonable agreement between observed and predicted low flows, especially for the Blue Nile Basin in 2003, even though there is underprediction for flows greater than $20 \mathrm{~mm} \mathrm{day}^{-1}$ for Anjeni. The underprediction of peak flows is likely caused by an expansion of runoff-producing 

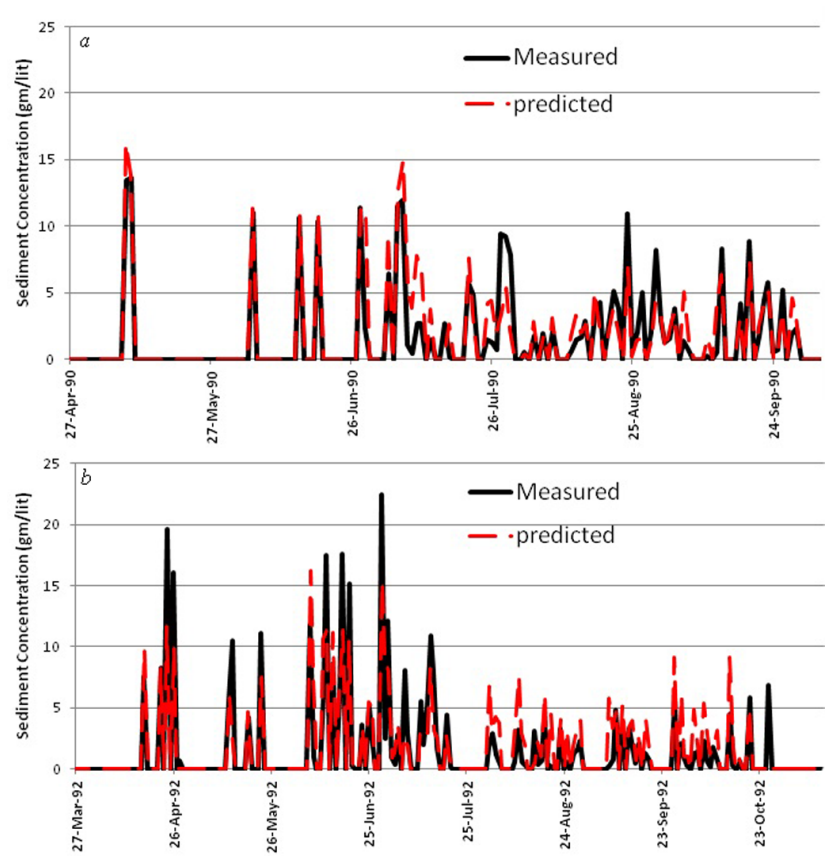

Fig. 6. Predicted and observed daily sediments concentration for the Anjeni watershed (a) calibrated 1990 and (b) validated period (shown only 1992).

areas during heavy storms of longer duration. This expansion is not captured, because our model fixes the fraction of the runoff-generating areas. The overestimation of low flows early in the period of 1988-1990 for Anjeni is likely due to the impact of the implementation of Fanya juu (SWC with bunds and drainage ditches) in the watershed in 1986. Initially water could be stored behind the bunds (decreasing discharge), but by 1990 the storage behind the bunds were filled up with sediment (Bosshart, 1997) and runoff increased thereafter.

In the Supplement we show that the hydrology model was only sensitive to fractional areas and one can assume that the fitted values in Table 2 are reasonably close to the optimum values. For the other model parameters, a wide range of values exists that give the same Nash-Sutcliffe efficiencies.

In summary, the simple model was able to simulate the discharge patterns quite well in the small 113 ha Anjeni watershed and large 17.4 million ha Blue Nile Basin watershed, with area fractions of degraded and hillslope zones that were approximately similar. The $R^{2}$ and NSE values obtained were equal or better than the simulation of Easton et al. (2010) for the SWAT-WB model, indicating that the concept of patterns of self-organization on a watershed scale is realistic. This pattern suggests that the initial rains following the dry season first need to replace the water that has been lost due to evaporation during the dry season before the watershed discharge can begin to respond to precipitation (Liu et al., 2008) from less than $1 / 3$ of the watershed. The remaining watershed is the source of baseflow and interflow.

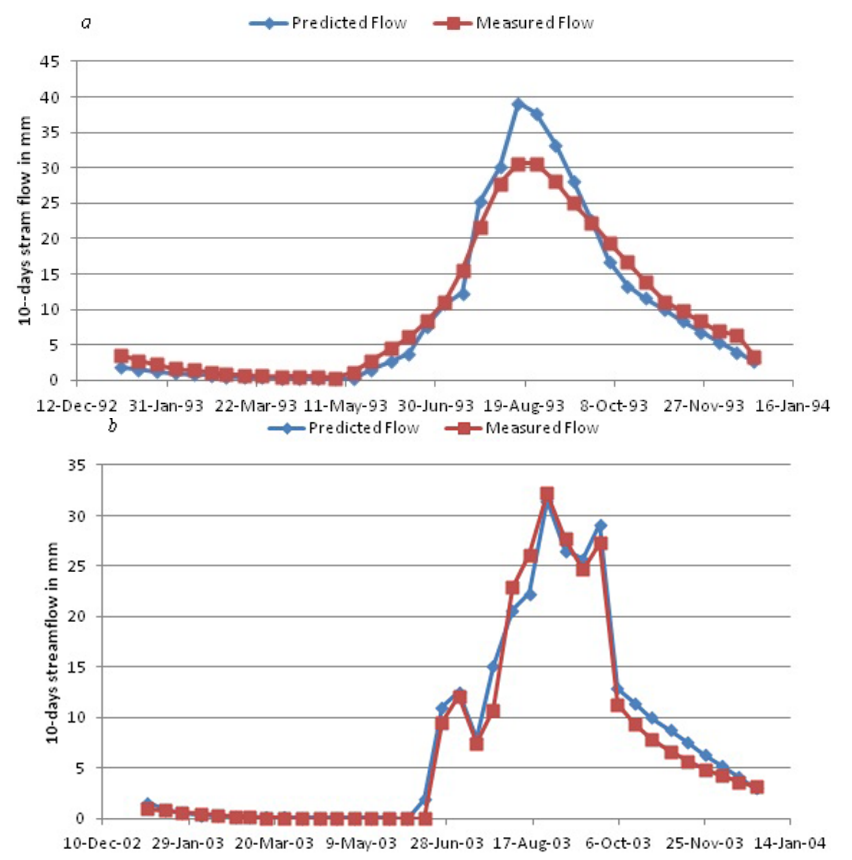

Fig. 7. Observed and predicted 10-day stream flow (mm/10-day) for the Blue Nile Basin at the Ethiopian-Sudan border. (a) calibration and (b) validation.

\subsection{Sediment model}

According to the hydrology model, there are two surface runoff source areas in the watershed. We assume that these runoff source areas are sources of sediment in our modeling. The simulation results fit quite well (Figs. 6 and 8, Table 3). The calibration results in Table 2 show that the degraded runoff source areas (represented by a constant $a_{2}$ in Table 2) generate most of the erosion. Because of the low proportion of level lands in the Anjeni watershed and the low coefficient value of $a_{1}$, sediment transported by runoff from saturated source areas was relatively low. The assumption that no sediment concentration is generated from interflow and baseflow seems to be reasonable as the agreement between observed and predicted sediment concentration deteriorates rapidly in the trial of increasing the coefficients $a_{\mathrm{I}}$ and $a_{\mathrm{B}}$ from zero. In the Supplement we showed that the sediment model was sensitive to the $a_{2}$ coefficient and one can assume that the fitted values in Table 2 are reasonably close to the optimum values.

The finding that a small portion of the watershed $(14 \%$ for Anjeni and $20 \%$ for Blue Nile Basin) delivers most of the sediment was also shown by Easton et al. (2010) for multiple watersheds in the Blue Nile Basin. The coefficient $a_{2}$ for degraded areas in Anjeni is three times higher than in the Blue Nile Basin (Table 2). This was expected because the Anjeni watershed has a much greater slope than the Blue Nile Basin. In Anjeni, these areas are located on the fields in which the farmers have traditional small drainage 


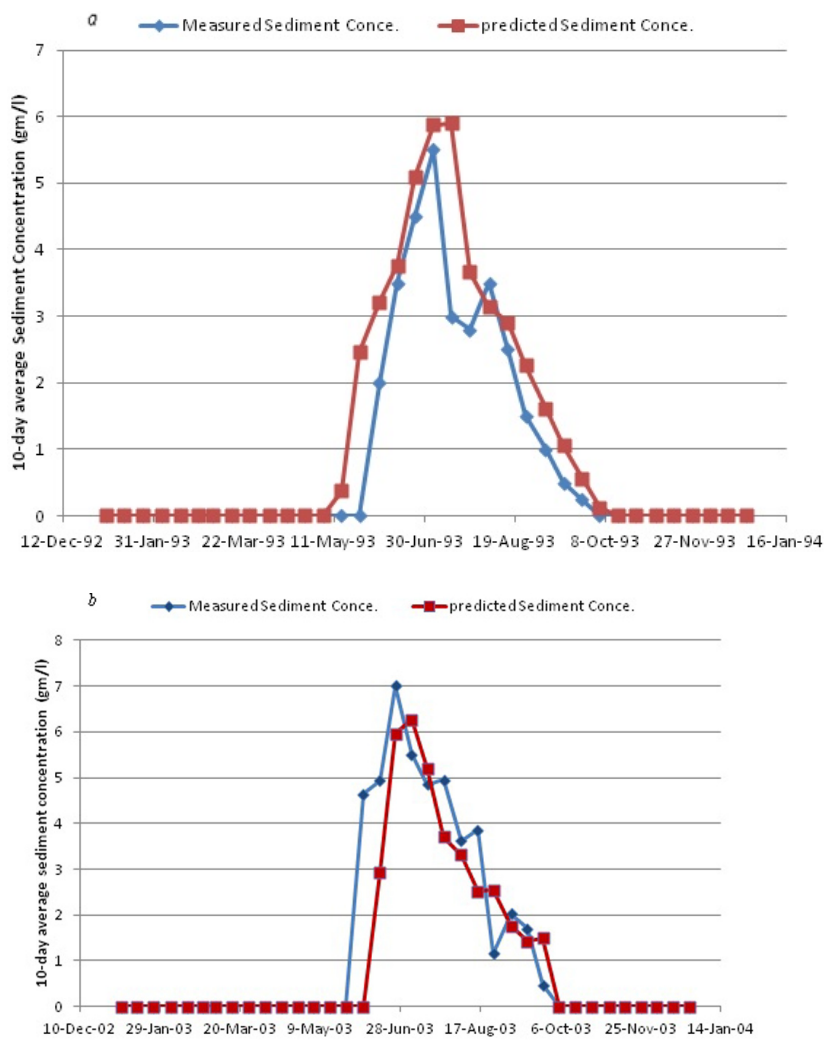

Fig. 8. The 10-day average sediment concentration $\left(\mathrm{g} \mathrm{L}^{-1}\right)$ (shown in b) for the Blue Nile Basin at the Ethiopian-Sudan border. (a) calibration and (b) validation.

(or cultural) ditches on shallow and slowly permeable soils (Leggesse, 2009) while in the Blue Nile Basin, the degraded areas are located at Mount Choke in East and West Gojam where Anjeni is located, Lake Tana subbasin, Jema subbasin in Wolo and Abay Gorge in East Wollega (Hydrosult Inc. et al., 2006).

Daily suspended sediment concentrations in the Anjeni watershed were simulated well. The coefficient of determination, $R^{2}$, was 0.8 for calibration and 0.67 for validation. The Nash-Sutcliffe efficiency of 0.78 for calibration and 0.64 for validation. These results are comparable with the work of Easton et al. (2010) in which the modified SWAT-WB for monsoonal climates was used and that of Zeleke (2000) which used WEPP. Our model uses only two parameters whereas SWAT and WEPP models incorporate more calibration parameters, such as plant cover, slope, soil and water management or soil type. Since such factors interact to affect soil erosion at a spot, choosing the correct values for each particular location is a very challenging task when only the integral sediment signal at the outlet is known. This makes sediment modeling very difficult. Therefore, getting these relatively high coefficients of determination and NSE for daily data using only two calibration parameters is very desirable for data scarce regions.
Despite the good fit, the model underpredicted during high sediment concentration measurements and overestimated during low sediment concentration measurements in Anjeni (Figs. 6 and 8) during the validation period specifically in 1992 and 1993. This is due to, first, the under- and overestimations in the hydrology model being propagated to the simulation of sediment concentration. Secondly, it is reported in Bosshart (1997) that poor maintenance of SWC in the watershed during these years resulted in higher sediment concentration values.

The incorporation of baseflow and interflow in the model helps to capture the lower sediment concentration after July for Anjeni Watershed (Figs. 6 and 8). In the Blue Nile Basin, it seems that baseflow and interflow play an important role in diluting the sediment after July and decreasing the sediment concentration. The drop and subsequent low sediment concentration at this time is similarly reported in Tigray, in the northern part of Ethiopia, by Vanmaercke et al. (2010). The authors argued that sediment depletion during this time reduced the sediment concentration in the streams. Others (Descheemaeker et al., 2006; Bewket and Sterk, 2003) suggested that the lower sediment concentrations are a result of the increased plant cover. Although this effect could exist, Tebebu et al. (2010) showed that such a relationship does not exist for Debre Mawi watershed in Blue Nile Basin.

The low sediment concentration measurements in 1989 due to SWC were difficult to capture using the model, and hence excluded from the data set. This justifies that incorporating more calibration parameters, such as SWC management for the different runoff areas, might improve the sediment concentration prediction.

\section{Conclusions}

A simplified watershed sediment model, coupled with a hydrology model, was developed and used to simulate sediment concentrations and runoff at two widely varying scales. Such simplified models that require very few calibration parameters to simulate runoff and sediment transport are important in data-limiting environments. Using these models, it was possible to identify the proportion of runoff-contributing areas, which are also sources of sediment. The analysis showed that the model could capture quite well the variability in discharge and sediment concentrations using parameter values that did not vary greatly between the scales. The model basically assumes in its simplest form that a watershed in a monsoon climate wets up after the dry season and produces increasing amounts of base- and interflow as the rainy season progresses. At the same time, this dilutes the sediment in the rivers that originates mainly from relatively small portions of degraded hillsides. More research is needed into how the model parameters vary between scales and watershed characteristics. 


\section{Supplementary material related to this article is available online at: http://www.hydrol-earth-syst-sci.net/ 17/1051/2013/hess-17-1051-2013-supplement.pdf.}

Acknowledgements. Funding was provided by the International Foundation for Science (IFS), Higher Education for Development (HED) and USDA International Science and Education (ISE) program. The runoff and sediment data were made available by Amhara Regional Agricultural Research Institute. Finally, we would like to thank Hans Hurni for providing the information we requested and foresight in establishing the Anjeni watershed for runoff and sediment data collection.

Edited by: E. Zehe

\section{References}

Bayabil, H. K., Tilahun, S. A., Collick, A. S., and Steenhuis, T. S.: Are runoff processes ecologically or topographically driven in the Ethiopian Highlands? The case of the Maybar, Ecohydrology, 3, 457-466, doi:10.1002/eco.170, 2010.

Betrie, G. D., Mohamed, Y. A., van Griensven, A., and Srinivasan, R.: Sediment management modelling in the Blue Nile Basin using SWAT model, Hydrol. Earth Syst. Sci., 15, 807-818, doi:10.5194/hess-15-807-2011, 2011.

Bewket, W. and Sterk, G.: Assessment of soil erosion in cultivated fields using a survey methodology for rills in Chemoga watershed, Ethiopia, Agr. Ecosyst. Environ., 97, 81-93, 2003.

Borga, M., Anagnostou, E. N., Bloeschl, G., and Creutin, J.D.: Flash flood forecasting, warning and risk management: the HYDRATE project, Environ. Sci. Pol., 14, 834-844, doi:10.1016/j.envsci.2011.05.017, 2011.

Bosshart, U.: Catchment Discharge and Suspended Sediment Transport as Indicators of Physical Soil and Water Conservation in the Minchet Catchment, Anjeni Research Unit, Soil Conservation Research Report 40, University of Berne, Berne, Switzerland, 1997.

Ciesiolka, C. A. A., Coughlan, K. J., Rose, C. W., Escalante, M. C., Hashim, G. M., Paningbatan Jr., E. P., and Sombatpanit, S.: Methodology for a multi-country study of soil erosion management, Soil Technol., 8, 179-192, 1995.

Champion, A. M.: Soil Erosion in Africa, Geogr. J., 82, 131-139, 1933.

Collick, A. S., Easton, Z. M., Ashagrie, T., Biruk, B., Tilahun, S., Adgo, E., Awulachew, S. B., Zeleke, G., and Steenhuis, T. S.: A simple semi distributed water balance model for the Ethiopian Highlands, Hydrol. Process., 23, 3718-3727, 2009.

Dahlke, H. E., Easton, Z. M., Walter, M. T., and Steenhuis, T. S.: Field Test of the Variable Source Area Interpretation of the Curve Number Rainfall-Runoff Equation, J. Irrig. Drain. Eng.-ASCE, 138, 235-244, 2012.

de Alwis, D. A., Easton, Z. M., Dahlke, H. E., Philpot, W. D., and Steenhuis, T. S.: Unsupervised classification of saturated areas using a time series of remotely sensed images, Hydrol. Earth Syst. Sci., 11, 1609-1620, doi:10.5194/hess-11-16092007, 2007.
Descheemaeker, K., Nyssen, J., Rossi, J., Poesen, J., Haile, M., Raes, D., Muys, B., Moeyersons, J., and Deckers, S.: Sediment deposition and pedogenesis in exclosures in the Tigray Highlands, Ethiopia, Geoderma, 132, 291-314, 2006.

Dooge, J. C. I.: Looking for Hydrologic Laws, Water Resour. Res., 22, S46-S58, 1986.

Dooge, J. C. I.: Bringing it all together, Hydrol. Earth Syst. Sci., 9, 3-14, doi:10.5194/hess-9-3-2005, 2005.

Easton, Z. M., Fuka, D. R., White, E. D., Collick, A. S., Biruk Ashagre, B., McCartney, M., Awulachew, S. B., Ahmed, A. A., and Steenhuis, T. S.: A multi basin SWAT model analysis of runoff and sedimentation in the Blue Nile, Ethiopia, Hydrol. Earth Syst. Sci., 14, 1827-1841, doi:10.5194/hess-14-1827-2010, 2010.

Engda, T. A., Bayabil, H. K., Legesse, E. S., Ayana, E. K., Tilahun, S. A., Collick, A. S., Easton, Z. M., Rimmer, A., Awulachew, S. B., and Steenhuis, T. S.: Watershed hydrology of the (semi) humid Ethiopian Highlands, in: Nile River: Hydrology, Climate and Land Use, edited by: Melesse, A., Springer Science Publisher, New York, 2011.

Eweg, H. P. A., Van Lammeren, R., Deurloo, H., and Woldu, Z.: Analyzing degradation and rehabilitation for sustainable land management in the highlands of Ethiopia, Land Degrad. Dev., 9, 529$542,1998$.

Fleitmann, D., Dunbar, R. B., McCulloch, M., Mudelsee, M., Vuille, M., McClanahan, T. R., Cole, J. E., and Eggins, S.: East African soil erosion recorded in a 300 year old coral colony from Kenya, Geophys. Res. Lett., 34, L04401, doi:10.1029/2006GL028525, 2007.

Garzanti, E., Ando, S., Vezzoli, G., Ali Abdel Megid, A., and El Kammar, A.: Petrology of Nile River sands (Ethiopia and Sudan): sediment budgets and erosion patterns, Earth Planet. Sc. Lett., 252, 327-341, 2006.

Hanggi, F.: Temporal and spatial variations of soil erosion in the Research Units Anjeni and Andit Tid: case studies of test plot soil erosion in the north western and central highlands of Ethiopia, SCRP research report 37, University of Berne, Berne, Switzerland, 1997.

Hairsine, P. B. and Rose, C. W.: Modeling water erosion due to overland flow using physical principles 1 . Sheet flow, Water Resour. Res., 28, 237-243, 1992a.

Hairsine, P. B. and Rose, C. W.: Modeling water erosion due to overland flow using physical principles 2 . Rill flow, Water Resour. Res., 28, 245-250, 1992b.

Haregeweyn, N. and Yohannes, F.: Testing and evaluation of the agricultural non-point source pollution model (AGNPS) on Augucho catchment, Western Hararghe, Ethiopia, Agr. Ecosyst. Environ., 99, 201-212, 2003.

Harpold, A. A., Lyon, S. W., Troch, P. A., and Steenhuis, T. S.: The hydrological effects of lateral preferential flow paths in a glaciated watershed in the Northeastern United States, Vadose Zone J., 9, 397-414, 2010.

He, Y., Bàrdossy, A., and Zehe, E.: A catchment classification scheme using local variance reduction method, J. Hydrol., 411, 140-154, 2011.

Hudson, N. W.: Erosion control research. Progress report on experiments at Henderson Research Station, 1953-1956, Rhodesia Agric. Jour., 54, 297-323, 1957.

Hudson, N. W.: Raindrop size distribution in high intensity storms. Rhod. J. Agr. Res., 1, 6-11, 1963. 
Hudson, N. W.: Soil and Water conservation in semi-arid areas, Soil Resources, Management and Conservation Service, FAO Land and Water Development Division, Food and Agriculture Organization of the United Nations, Rome, 1987.

Hurni, H.: An ecosystem approach to soil conservation, in: Soil Erosion and Conservation, edited by: El-Swaify, S. A., Moldenhauer, W. C., and Lo, A., Soil Conservation Society of America, Ankey, Iowa, 759-771, 1985.

Hurni, H.: Degradation and conservation of the resources in the Ethiopian Highlands, Mt. Res. Dev., 8, 123-130, 1988.

Hydrosult Inc., Techsult, DHV, their Associates Nile Consult, Comatex Nilotica, and T and A Consulting: Trans-Boundary Analysis: Abay - Blue Nile Sub-basin. NBI-ENTRO (Nile Basin Initiative-Eastern Nile Technical Regional Organization), 2006.

Kandel, D., Western, A., Grayson, R., and Turral, H.: Testing current generation soil erosion models at two minute and daily scales using plot scale data from a mid-hill catchment of Nepal, in: Integrating Models for Natural Resources Management Across Disciplines, Issues and Scales, edited by: Ghassemi, F., Post, D., Sivapalan, M., and Vertessy, R., Proceedings of the International Congress on Modelling and Simulation (MODSIM 2001), Volume 1: Natural Systems Modelling and Simulation Society of Australia and New Zealand Inc., Australian National University, Canberra, Australia, 365-370, 2001.

Kim, Y.-J., Darnault, C. J. G., Bailey, N. O., Parlange, J.-Y., and Steenhuis, T. S.: Equation for describing solute transport in field soils with preferential flow paths, Soil Sci. Soc. Am. J., 69, 291300, 2005.

Klaus, J. and Zehe, E.: A novel explicit approach to model bromide and pesticide transport in connected soil structures, Hydrol. Earth Syst. Sci., 15, 2127-2144, doi:10.5194/hess-15-21272011, 2011.

Kung, K.-J. S., Steenhuis, T. S., Kladivko, E. J., Gish, T. J., Bubenzer, G., and Helling, C. S.: Impact of Preferential Flow on the Transport of Adsorbing and Non-Adsorbing Tracers, Soil Sci. Soc. Am. J., 64, 1290-1296, 2000.

Lal, R.: Soil erosion and transport research in tropical Africa, Hydrolog. Sci., 30, 239-256, 1985.

Leggesse, E. S.: Modelling Rainfall-Runoff Relationships for the Anjeni watershed in the Blue Nile Basin, A Thesis Presented to the Faculty of the Graduate School of Cornell University In Partial Fulfillment of the Requirements for the Degree of Master of Professional Studies, Ithaca, NY, 2009.

Lisle, I. G., Coughlan, K. J., and Rose, C. W.: GUPRO 3.1: A program for calculating particle size and settling characteristics, ENSWorking Paper 7/96. Faculty of Environmental Sciences, Griffith University, Brisbane, 1996.

Liu, B. M., Collick, A. S., Zeleke, G., Adgo, E., Easton, Z. M., and Steenhuis, T. S.: Rainfall discharge relationships for a monsoonal climate in the Ethiopian Highlands, Hydrol. Process., 22, 10591067, 2008.

Lyon, S. W., Lembo, A. J., Walter, M. T., and Steenhuis, T. S.: Defining Probability of Saturation With Indicator Kriging on Hard and Soft Data, Adv. Water Resour., 29, 181-93, 2006.

Mitiku, H., Herweg, K., and Stillhardt, B.: Sustainable land management - a new approach to soil and water conservation in Ethiopia, Land Resource Management and Environmental Protection Department, Mekelle University, Mekelle, Ethiopia, Center for Development and Environment (CDE), University of Bern and Swiss National Center of Competence in Research (NCCR) North-South, Bern, Switzerland, 269 pp., 2006.

Mohammed, A., Yohannes, F., and Zeleke, G.: Validation of agricultural non-point source (AGNPS) pollution model in Kori watershed, South Wollo, Ethiopia, Int. J. Appl. Earth Obs., 6, 97-109, 2004.

Nyssen, J., Poesen, J., Moeyersons, J., Haile, M., Deckers, J., and Lang, A.: Human impacts on the environment in the Ethiopian and Eritrean Highlands - a states of the art, Earth Sci. Rev., 64, 270-320, 2004.

Prosser, I. P. and Rustomji, P.: Sediment transport capacity relations for overland flow, Prog. Phys. Geogr., 24, 179-193, 2000.

Rimmer, A. and Hartmann, A.: Simplified conceptual structures and analytical solutions for groundwater discharge using reservoir equations. Chapter 10 in InTech Open Access book, "Water Resources Management and Modeling”, ISBN 978-953-51-0246-5, 2012.

Rose, C. W.: Erosion and sedimentation, in: Hydrology and Water Management in the Humid Tropics-Hydrological Research Issues and Strategies for Water Management, edited by: Bonnell, M., Hufschmidt, M. M., and Gladwell, J. S., Cambridge University Press, Cambridge, 301-343, 1993.

Rose, C. W.: Soil erosion models and implications for conservation of sloping tropical lands, in: Sustaining the Global Farm- Selected papers from the 10th International Soil Conservation Organization Meeting, 24-29 May 1999, West Lafayette, IN, International Soil Conservation Organization in cooperation with the USDA and Purdue University, West Lafayette, edited by: Stott, D. E., Mohtar, R. H., and Steinardt, G. C., CD-ROM available from the USDA-ARS National Soil Erosion Laboratory, West Lafayette, 852-859, 2001.

Savenije, H. H. G.: HESS Opinions "Topography driven conceptual modelling (FLEX-Topo)", Hydrol. Earth Syst. Sci., 14, 26812692, doi:10.5194/hess-14-2681-2010, 2010.

SCRP: Area of Anjeni, Gojam, Ethiopia: long-term monitoring of the agricultural environment 1984-1994, Soil erosion and conservation database, Soil Conservation Research Programme (SCRP), Centre for Development and Environment and the Ministry of Agriculture, Ethiopia, University of Berne, Berne, Switzerland, 89 pp., 2000.

Setegn, S. G., Ragahavan, S., and Bijan, D.: Hydrological modelling in the Lake Tana Basin, Ethiopia using SWAT model, Open Hydrol. J., 2, 49-62, 2008.

Siepel, A. C., Steenhuis, T. S., Rose, C. W., Parlange, J.-Y., and McIsaac, G. F.: A simplified hillslope erosion model with vegetation elements for practical applications, J. Hydrol., 258, 111121, 2002.

Sivapalan, M., Yaeger, M. A., Harman, C. J., Xu, X., and Troch, P. A.: Functional model of water balance variability at the catchment scale: 1 . Evidence of hydrologic similarity and space-time symmetry, Water Resour. Res., 47, W02522, doi:10.1029/2010WR009568, 2011.

Steenhuis, T. S. and van der Molen, W. H.: The ThornthwaiteMather procedure as a simple engineering method to predict recharge, J. Hydrol., 84, 221-229, 1986.

Steenhuis, T. S., Collick, A. S., Easton, Z. M., Leggesse, E. S., Bayabil, H. K., White, E. D., Awulachew, S. B., Adgo, E., and Ahmed, A. A.: Predicting discharge and erosion for the Abay (Blue Nile) with a simple model, Hydrol. Process., 23, 3728- 
3737, 2009.

Tebebu, T. Y., Abiy, A. Z., Zegeye, A. D., Dahlke, H. E., Easton, Z. M., Tilahun, S. A., Collick, A. S., Kidnau, S., Moges, S., Dadgari, F., and Steenhuis, T. S.: Surface and subsurface flow effect on permanent gully formation and upland erosion near Lake Tana in the northern highlands of Ethiopia, Hydrol. Earth Syst. Sci., 14, 2207-2217, doi:10.5194/hess-14-2207-2010, 2010.

Tesemma, Z. K., Mohamed, Y. A., and Steenhuis, T. S.: Trends in rainfall and runoff in the Blue Nile Basin: 1964-2003, Hydrol. Process., 24, 3747-3758, doi:10.1002/hyp.7893, 2010.

Thomas, D. B. and Biamah, E. K.: Origin, application and design of fanya juu terrace, in: Development of Conservation Farming on Hillslopes, edited by: Moldenhauer, W. C., Hudson, N. W., Sheng, T. C., and Lee, S. W., Soil and Water Conservation Society, Ankeny, Iowa, 185-194, 1991.

Thornthwaite, C. W. and Mather, J. R.: The water balance, Publ. Climatol., 8, 1-104, 1955.

Vanmaercke, M., Zenebe, A., Poesen, J., Nyssen, J., Vertstraeten, G., and Deckers, J.: Sediment dynamics and the role of flash floods in sediment export from medium-sized catchments: a case study from the semi-arid tropical highlands in Northern Ethiopia, J. Soil Sediment., 10, 611-627, 2010.

Vanmaercke, M., Poesen, J., Maetens, W., Vente, J., and Verstraeten, G.: Sediment yield as a desertification risk indicator, Sci. Total Environ., 409, 1715-1725, doi:10.1016/j.scitotenv.2011.01.034, 2011.

Western, A. W., Grayson, R. B., and Blöschl, G.: Scaling of soil moisture: A Hydrologic Perspective, Annu. Rev. Earth Pl. Sc., 30, 149-180, 2002.
Wischmeier, W. H. and Smith, D. D.: Predicting rainfall erosion losses - a guide to conservation planning, USDA Agric. Handbook, 537, 58 pp., 1978.

White, E. D., Easton, Z. M., Fuka, D. R., Collick, A. S., Adgo, E., McCartney, M., Awulachew, S. B., Selassie, Y., and Steenhuis, T. S.: Development and application of a physically based landscape water balance in the SWAT model, Hydrol. Process., 23, 37283737, doi:10.1002/hyp.7876, 2010.

Yu, B., Rose, C. W., Ciesiolka, B. C. A. A., Coughlan, K. J., and Fentie, B.: Toward a framework for runoff and soil loss prediction using GUEST technology, Aust. J. Soil Res., 35, 1191-1212, 1997.

Zehe, E., Graeff, T., Morgner, M., Bauer, A., and Bronstert, A.: Plot and field scale soil moisture dynamics and subsurface wetness control on runoff generation in a headwater in the Ore Mountains, Hydrol. Earth Syst. Sci., 14, 873-889, doi:10.5194/hess14-873-2010, 2010.

Zegeye, A. D., Steenhuis, T. S., Blake, R. W., Kidnau, S., Collick, A. S., and Dadgari, F.: Assessment of Upland Erosion Processes and Farmer Perception of Land Conservation in DebreMewi Watershed, near Lake Tana, Ethiopia, Ecohydrologica, 10, 297-306, 2010.

Zeleke, G.: Landscape Dynamics and Soil Erosion Process Modeling in the North-Western Ethiopian Highlands, African Studies Series A 16, Geographica Bernensia, Berne, Switzerland, 2000. 